\title{
Urgensi Sejarah Sosial Sebagai Konsep Teoritik Bagi Living Hadith di Indonesia
}

\author{
Subkhani Kusuma Dewi \\ UIN Sunan Kalijaga - Yogyakarta \\ kusummadewi@gmail.com
}

\begin{abstract}
The perspective on Islamic history has become an important topic of discussion in Islamic studies. Its existence, at the same time, is also very helpful in the study of texts, such as the interpretation of the Alqur'an or riwâyat and dirâyat studies of Hadith. But the existence of social history as a new theoretical concept came later. A perspective that emphasizes on the sociological aspects of a collection of events, social history also puts forward the process of criticism in it, as has been done by peripheral social history. In the first sub-chapter, this article needs to show that such a perspective has long been carried out by Muslim historians, such as Ibn Khaldun, or Hamzah Al-Sam'ani's Tarikh Jurjan. Unlike the political perspective, the history of Muslim societies have varieties of fragments, different kinds of local tradition and focus on social history. The second part of this article proves that the existence of $i j a \hat{z} a b$ (authorization) as a juristic authority through the tradition of sanad is another way of the documentation for the transmission (or also transformation) of Hadith in the community. Hadith authority does not take place statically. Social history narratives in this context will be able to provide evidence that authority of Hadith local religious leaders would not be possible if there were no community acceptance as explored by its various dimensions (economic, social, political, religious) through social history.
\end{abstract}


[Cara pandang terhadap sejarah islam telah menjadi topik diskusi penting dalam studi Islam. Keberadaannya, pada saat yang sama, juga amat membantu studi teks, seperti tafsir Qur'an ataupun studi riwâyat dan dirâyat Hadith. Tetapi keberadaan sejarah sosial sebagai sebuah konsep teoritik baru datang belakangan. Sebuah cara pandang yang menekankan pada aspek sosiologis sebuah kumpulan peristiwa, sejarah sosial juga mengedepankan proses kritisisme di dalamnya, seperti yang telah dilakukan oleh sejarah sosial pingiran. Pada sub-bab pertama, artikel ini berkebutuhan untuk menunjukkan bahwa cara pandang seperti ini telah lama dilakukan oleh sejarawan muslim, seperti Ibn Khaldun, ataupun Tarikh Jurjan karya Hamzah Al Sam'ani. Berbeda dengan perspektif politik, sejarah masyarakat muslim adalah ragam fragmen, ragam sejarah lokal yang berbeda-beda, focus pada sejarah sosial. Bagian kedua dari artikel ini membuktikan bahwa keberadaan ijâzah (otorisasi) sebagai penyambung otoritas keulamaan melalui tradisi sanad merupakan bahasa lain dari dokumentasi transmisi (atau juga transformasi) Hadith di masyarakat. Otoritas Hadith tidak berlangsung secara statis. Narasi sejarah sosial pada konteks ini akan mampu menyuguhkan bukti bahwa suatu otoritas atau kewenangan Hadith para local religious leaders tidak akan mungkin diakui bila tidak ada penerimaan masyarakat sebagaimana diekplorasi ragam dimensinya (ekonomi, sosial, politik, agama) melalui sejarah sosial.]

Kata kunci: social history, transmission of hadith, authorization, sanad

\section{Pendahuluan}

Masyarakat muslim dunia kini hidup pada fase krusial dimana mereka berusaha sekuat tenaga untuk mendapatkan petunjuk dan dukungan bagi masa depan melalui ilustrasi dan gambaran tentang sejarah Islam di masa klasik yang didapat melalui para generasi terdahulu. Sementara pada saat yang sama, para intelektual non-muslim sedang menguji sejarah yang sama tetapi untuk mengetahui sejarah sosial kehidupan masyarakat muslim dan memperkirakan masa depan 
gerakan islam kontemporer. Kedua usaha yang sedang terjadi ini sama-sama berlandaskan pada sejarah Islam. ${ }^{1}$

Keterlibatan perspektif ilmu sosial sebagai pendekatan baru dalam kajian living phenomenon of hadith bagi beberapa kalangan dianggap sebagai suatu terobosan keilmuan yang baru. Rumpun keilmuan sosial seperti sejarah, sosiologi, antropologi dilihat sebagai studi yang tidak memiliki kemiripan akar dari keilmuan hadith klasik (ulum al-hadith) sehingga perlu ada upaya pengintegrasian keduanya. Bukan itu saja, asumsi umum ini juga didukung oleh obyek material dari kajian living phenomenon of hadith yang sedikit bergeser dari keilmuan ulum al-hadith klasik yang menekankan pada telaah lebih jauh bagaimana masyarakat muslim melakukan

interpretasi (penafsiran) dan sesuai terhadap kekayaan sunnah maupun hadith. Kebutuhan untuk mengintegrasikan kedua rumpun ini merupakan perkembangan terbaru dari studi ini. ${ }^{2}$

Asumsi di atas bukan tidak sepenuhnya salah bila kita melihat konsep teoritik living hadith sebagai dua hal sekaligus; pertama sebagai sebuah cara pandang baru terhadap studi hadith yang dalam beberapa aspeknya mengalami kemunduran, kedua sebagai respon akademik para pegiat studi hadith di Indonesia karena melihat adanya gap antara hadith sebagai obyek kajian akademik dengan hadith sebagaimana dihayati dan diaplikasian masyarakat muslim Indonesia dalam kehidupan mereka. Tidak bisa dipungkiri, dua alasan tersebut sepenuhnya dapat dilihat sebagai fenomena kontemporer kajian hadith di Indonesia. ${ }^{3}$

Tetapi sebenarnya kebutuhan untuk memperdalam gagasan baru ini sangat mendesak terutama dalam hal perspektif keilmuan yang harus selalu ada. Artikel ini berusaha untuk membantu menyinggungnya melalui perspektif sejarah sosial secara lebih detail. Tujuan artikel ini adalah untuk menjawab bagaimana pergeseran atau pertumbuhan studi hadith yang sesungguhnya membutuhkan perspektif yang

${ }^{1}$ Richard Bulliet, Islam, The view from The Edge (USA: Columbia University Press, 1994), 8.

2 Benny Afwadzi, Membangun Integrasi Ilmu-ilmu Sosial dan Hadith Nabi, Jurnal Living Hadith, Vol. 1, No. 1, 2016. ejournal.uinsuka.ac.id/ushuluddin/Living/article/view/0101-05. DOI: https://doi.org/ 10.14421/ livinghadith.2016.0101-05.

3 Saifuddin Zuhri Qudsy, Living Hadith; Genealogi, Teori, dan Aplikasi, Jurnal Living Hadith, Vol. 1, No. 1, 2016. Ejournal.uin-suka.ac.id/ushuluddin/Living/ article/view/0101-08.

DOI: https://doi.org/10.14421/livinghadith.2016.0101-08. 
berbeda dari tradisi keilmuan terdahulu. Sejarah sosial pinggiran (periphery) dalam beberapa aspeknya memiliki kontribusi untuk mengokohkan studi living hadith.

\section{Problematika Otentisitas Hadith Sebagai Bagian dari Sejarah Sosial}

Dalam bukunya Muqaddimah, Ibn Khaldun menyayangkan cara para narrator sejarah dalam mengungkapkan sejarah peradaban Islam yang cenderung taklidi (konvensional), hanya mengikuti pola penulisan sejarah yang sudah ada dan lalai terhadap perubahan-perubahan masa dan tradisi-tradisinya dari generasi ke generasi." ${ }^{4}$ Khaldun menilai bahwa dokumentasi sejarah dengan metode kronologis ini hanya mampu menumpuk kertas tanpa berkontribusi dalam hal pembaharuan metode dan perspektif, sehingga — seakan-akandokumentasi sejarah tidak memiliki kontribusi progresif bagi generasi sesudahnya. Pergantian situasi dan kondisi sosial yang dialami bangsabangsa dari generasi ke generasi juga diabaikan, sehingga perubahan sosial kemasyarakatan yang terjadi pada suatu masa tertentu tidak terekam dengan baik. Melainkan perubahan antar generasi manusia adalah hal niscaya. ${ }^{5}$ Ibnu Khaldun memformulasikan pemikirannya demikian, "Secara metodis sejarah merupakan usaha reflektif atas perilaku dan sampel positif dari pola bidup masyarakat terdabulu, dan memiliki tujuan untuk. memberikan daya proyektif bagi generasi mendatang”. Prasyarat utama dari menarasikan sejarah dengan tujuan seperti ini adalah keragaman referensi dan sumber informasi yang dimiliki oleh seorang narrator, sehingga berguna untuk mengeliminir problem keakuratan sumber. Menarasikan sejarah, menurut Khaldun, pada dasarnya bukan hanya tentang menuliskan kronologis peristiwa.

Dari sini kita bisa melihat perspektif baru sekaligus berbeda dari penulisan sejarah menurut Ibn Khaldun. Syarat utama bagi penulisan sejarah yang progresif, bagi Khaldun, dimulai dari obyek materialnya yang mencakup pula sebab-sebab tindakan dan perubahan pada masa lalu dan agama-agama, prasyarat suatu peradaban sehingga ia bisa membentuk sebuah kerajaan, agama, kota, budaya cara berpakaian, ilmu dan keahlian, kondisi perkotaan, pedesaan, yang kesemuanya berubah-ubah secara umum.

4 Ibn Khaldun, Muqaddimah Ibn Khaldun, terjemah Masturi Irham, dkk. (Jakarta: Pustaka Al Kautsar, 2001), 12.

${ }^{5}$ Ibid., 47. 
Pada generasi berbeda, perdebatan tentang keabsahan dan otentisitas Hadith yang masuk ke dalam ruang lingkup studi sarjana muslim pada dasarnya juga merupakan problem perspektif ilmu sejarah. Terutama, hal ini, disebabkan oleh studi yang dilakukan oleh para orientalisrevisionis yang juga meragukan sumber sejarah Hadith, sehingga berakibat pada keraguan mereka atas derajat otentisitas Hadith. ${ }^{6}$ Dengan menggunakan metode kritik sumber (source-critical methods), dan temuan-temuan arkeologi; nama-nama seperti Ignaz Goldziher, Joseph Schacht, dan G.H.A. Juynboll memandang sumber-sumber dari kalangan Islam dengan daya kritis dan skeptis yang begitu tinggi. Mereka tidak begitu saja mempercayai keautentikannya sebelum terbukti bahwa sumber itu benar-benar teruji dengan metode kritik sumber. John Wansbrough, sebagai contoh, yang menyatakan bahwa sumber-sumber tertulis, apapun sumber tertulis itu termasuk juga sumber-sumber muslim, tidak dapat bercerita kepada kita tentang "what really happened", tetapi hanya menggambarkan apa yang dianggap atau dipikirkan oleh penulis sumber itu sebagai peristiwa yang telah terjadi. Sebuah serangan yang cukup mengguncang keyakinan pengetahuan para sarjana dan umat Islam berkenaan dengan kekayaan khazanah sunnah antara lain adalah pendapat mereka bahwa Hadith sepenuhnya buatan umat Islam dan patut diragukan derajat ketawaturannya hingga Nabi Muhammad. ${ }^{7}$ Dibalik gegar otoritas ini, ternyata dari perspektif keilmuan sejarah kita bisa melihat cara pandang berbeda yang dimiliki oleh salah satu orientalis, yakni Nabia Abbott. Dari segi sumber sejarah, Nabia berusaha mengambil sumber referensi berbeda dengan tokoh orientalis lainnya. Ia tidak sepenuhya meragukan derajat otentisitas Hadith, dan berusaha untuk melakukan refleksi atas sumber sejarah (dengan metode filologi) yang diteliti. Langkah yang dilakukan oleh Nabia adalah menelaah faktor "when', 'why', and 'bow' of the origin and early method of Islamic historiography." Langkah Nabia yang tidak banyak dilakukan oleh orientalis lain misalnya adalah sumber sejarah yang ia ambil dari para story-tellers, reporter, juga sejarawan mencakup bukan saja referensi politik dan legal formal sejarah umat Islam, tetapi juga kehidupan sosial mereka. Meski belum sepenuhnya dapat disimpulkan, tetapi referensi

6 Ali Masrur, Diskursus Metodologi Studi Hadith Kontemporer Analisa Komparatif antara Pendekatan Tradisional dan Pendekatan Revisionis, Journal of Qur'ân and Hadìth Studies Vol. 1, No. 2 Tahun 2012, 237-249.

7 Dalam studi hadith orientalis, pendapat-pendapat seperti ini diwakili, misalnya, oleh Ignaz Golziher, Jospeh Schact, hingga HGA. Juynboll. 
manuskrip yang beragam turut berpengaruh terhadap kesimpulan kajian yang lebih komprehensif. ${ }^{8}$

Terobosan pendekatan yang berbeda dari para sejarawan di atas telah menunjukkan bahwa gagasan keilmuan boleh saja baru, tetapi yang tidak mudah kita dapatkan adalah sebuah perspektif berbeda dalam melihat suatu obyek studi. Termasuk di dalamnya sejarah sosial sebagai sebuah perspektif berbeda dalam penulisan historiografi.

Sejarah sosial pada dasarnya merupakan penulisan sejarah yang menempatkan masyarakat sebagai bahan utama dan titik pijak utama sebuah kajian. Artinya historiografi bukan diawali dari eksplorasi tentang para penguasa atau kaum elit. Sebaliknya historiografi diawali dari bawah, yaitu dari rakyat yang populis. Dengan demikian proses sejarah tidak ditentukan oleh dinamika politik, tetapi dinamika masyarakat pada umumnya. Penulisan sejarah sosial memerlukan usaha untuk membuat kerangka utuh mengenai masyarakat secara keseluruhan.'

Seperti yang dilakukan oleh Ibnu Khaldun dan Nabia Abbott, sejarah sosial bukan hanya membahas kaum elite atau tokoh, tetapi membahas hal-hal yang menyangkut struktur sosial, mobilitas sosial, dan juga hubungan-hubungan sosial masyarakat muslim. Komprehensifitas dan kompleksitas cakupan kajian sejarah sosial dari masyarakat muslim justru dimulai dari sejarah yang sifatnya lokal dan pinggiran (periphery).

\section{Otoritas Keilmuan Menurut Cara Pandang Sejarah Sosial (Pinggiran)}

8 Nabia Abbott, "Early Islamic Historiography", dalam Studies in Arabic Literary Papyri I: Quranic Commentary and Tradition (Illinois: The University of Chicago Press, 1967), 5-6.

${ }^{9}$ Kuntowijoyo, Metodologi Sejarah, (Yogyakarta: Penerbit Tiara Wacana, 2003), 42. Di Barat, perkembangan perspektif sejarah sosial dimulai dengan dipublikasikannya majalah Annales d' historie sociale economique di tahun 1929 yang menekankan anti-tesis dari pemikiran sejarah politik. Cara pandang Annales menekankan kehidupan sosial dari amsyarakat feudal. Karya sejarawan sosial yang cukup terkemuka di era itu adalah tulisan Fernard Braudel yang mencakup makanan, gaya hidup, pola sosial, dan perdagangan. Peter Burke, Sejarah Sosial dan Teori Sosial, edisi kedua, (Jakarta: Yayasan Pustaka Obor Indonesia, 2015) Sementara itu karya sejarah sosial masyarakat Indonesia dimulai dari tulisan Sartono Kartodirdjo Pemberontakan Petani Banten 1888, yang lebih menekankan pada pendekatan multidisipliner (bukan hanya bertumpu pada analisa politik) dengan cara menuliskan seajraah perspektif masyarakat bawah. Kuntowijoyo, Metodologi Sejarah, (Yogyakarta: Penerbit Tiara Wacana, 2003). 
Adalah Richard Bulliet melalui karyanya Islam, The View from The Edge yang telah menggunakan perspektif sejarah sosial bagaimana Hadith sampai dan dipelajari oleh masyarakat Jurjan, Iran pada abad ke 2-3 Hijriyah, saat Islam mengalami proses perkembangan ke daerah nonArab. Masyarakat Jurjan adalah sepenuhnya non-Arab, mereka tidak pernah mengalami sendiri emosi yang mengiringi masyarakat Mekkah dan Madinah dalam pertemuan keseharian dengan Nabi. Pun, masyarakat Jurjan telah memiliki keyakinan dan budaya saat Islam datang pada ruang lingkup sosial mereka. Kalaupun mereka akhirnya beriman kepada Allah, kepada Muhammad, itu karena mereka mempelajarinya setelah masuk Islam. Bahkan dapatlah disebutkan bahwa pemahaman mereka terhadap Islam tersebut pun sebenarnya berbeda-beda.

Penting untuk juga untuk juga ditelisik, kenapa harus Jurjan, daerah pinggiran Iran yang merupakan perbatasan antara Asia Tengah dengan Asia Selatan? Apa yang penting dari meneliti tentang peralihan keimanan bahkan identitas budaya masyarakat Jurjan? Terlebih lagi Jurjan adalah daeraah yang sama sekali tidak diperhitungkan dalam narasi sejarah Islam global, narasi sejarah Islam mainstream. Perspektif sejarah sosial adalah salah satu jawaban utama dari pertanyaanpertanyaan ini. Bulliet tidak hanya mengunakan perspektif sejarah sosial, tetapi juga ia membangun perspektif kritis yakni keberpihakannya pada sejarah masyarakat area pinggiran (peripheral areas). Sejarah sosial tidak cukup puas dengan melihat Islam secara politis. Dan sejarah sosial pinggiran juga tidak berhenti pada pengungkapan Islam melalui pusatnya, yakni dari historiografi kekhalifahan, kekuasaan politik. Cara pandang ini lebih tertarik untuk mengungkapkan fakta sejarah tentang otoritas keagamaan yang ada di masyarakat pinggiran, yakni menjawab pertanyaan utama, "selain kekhalifahan adakah aspek lain yang dapat menghidupkan kobesi sosial masyarakat muslim?" "1

Dari problem utama inilah kemudian Bulliet mengulas tentang sejarah sosial masyarakat Jurjan, serta yang paling penting adalah persoalan otoritas hadith sebagaimana diperankan oleh tokoh-tokoh ulama agama tingkat lokal. Pertanyaan penting Bulliet dari riset terhadap masyarakat Jurjan adalah; otoritas apa yang dimiliki oleh seorang

\footnotetext{
${ }^{10}$ Bulliet, Islam, The view, 8.

${ }^{11}$ Ibid., 5.
} 
ulama $^{12}$ di daerah Jurjan, sehingga mereka begitu disegani, dan para awam merasa terpuaskan saat mendapatkan kebenaran dari ungkapanungkapan mereka. Padahal seorang dai (khatib), atau pegawai kerajaan, bisa saja menjawab persoalan tersebut. Jawabannya, menurut hipotesa Bulliet, karena para ulama itu memiliki akar otoritas agama, karenanya saat ia menajawab pertanyaan si murid awam melihat pula dari sisi kesalehan, latar belakang, dan tradisi pembelajaran agama yang diikuti oleh ulama tersebut, juga pertanda lain yang semakin mengukuhkan otoritas keagamannya.

Selain menjawab persoalan khusus perihal sejarah otoritas Hadith di masyarakat Jurjan, Bulliet juga menjelaskan pentingnya perspektif sejarah sosial yang memfokuskan obyek kajiannya pada masyarakat pinggiran. Persoalan-persoalan seperti bagaimana bisa masyarakat muslim seluruh dunia, yang secara budaya beragam, mampu bersatu dan dengan mudah menerima Islam? Kalaupun jawabannya karena label agama itu sendiri, maka pertanyaan penting lainnya adalah "apa peran agama pada masyarakat muslim tersebut. Kepada siapa masyarakat awam itu menaruh kepatuhan mereka. Siapa juga yang merespon kebutuhan-kebutuhan masyarakat awam ini. ${ }^{13}$ Dari sini kita bisa menarik kesimpulan, bahwa perspektif sejarah sosial yang menekankan tentang "the view from the edge", berusaha untuk melengkapi cara pandang Islam yang secara dominan dilihat dari

\footnotetext{
12 Penyebutan ulama pada buku ini secara spesifik merujuk pada para murid pencari ilmu yang memfokuskan kehidupan mereka dalam mengumpulkan, mempelajari, menyebarkan, bahkan mempraktikan hadith di dalam hidupnya. Kata ulama dibedakan dari hafidz, mufassir, juga qari' yang saat itu mulai terbagi-bagi menurut kehalian mereka dalam hal teks agama. Menariknya, karakteristik seorang ulama juga mencakup di dalamnya seseorang yang shaleh dan juga sufi. Dengan demikian, menurut perspesi masyarakat Jurjan, "ulama adalah mereka yang memiliki otoritas dalam hal hadith, sekaligus menunjukan sifat keteladanan sebagai waratsatul anbiya' dalam keseharian mereka". Seperti diuraikan oleh Bulliet, melalui manuskrip yang ditulis oleh Hamzah al-Sam'ani, pembelajaran hadith bersifat sangat personal, para murid mencari guru, mereka belajar hadith dan menuliskannya pada kertas-kertas yang dimiliki secara personal. Selain faktor penulisan, faktor yang amat penting dalam transmisi hadith di Jurjan adalah faktor transmisi oral. Artinya, murid tidak sekedar memindahkan hadith ke dalam kumpulan manuskrip mereka, tetapi penghafalan, bahkan proses meneladani guru adalah bagian dari transmisi hadith itu sendiri. Matan-matan hadith juga bersifat local, selain tentu faktor ijazah juga bersifat personal. Bahkan ijazah merupakan unsur yang paling penting dalam transmisi ini. Bulliet mengulas, seorang anak dari pencari hadith pun tidak memiliki keberanian untuk mempelajari dan menggunakan manuskrip tulisan ayahnya, bila ia tidak mendapatkan ijazah dari sang ayah ataupun guru dari sang ayah. Bulliet, Islam, The View, 105.

${ }^{13}$ Bulliet, Islam, The View, 8
} 
pusat, dari aspek politis, yang serba formal dan bersifat legalistif. Cara pandang seperti ini bukan bermaksud untuk menggantikan cara pandang sejarah-pusat, sebaliknya, dengan menjawab dinamika keberagamaan dan menelaah peran-peran otoritatif lokal, sejarah sosial berusaha untuk melengkapi historiografi masyarakat muslim yang ada.

\section{Metode dalam Sejarah Sosial}

Karakter sejarah sosial yang bersifat interdisipliner ini menekankan metode penelitian yang berporos pada aspek empirikal dan investigatif terhadap sumber referensi (manuskrip). Kuntowijoyo, salah satu guru besar sejarah Indonesia, menyebutkan karakter ini sebagai heuristik. Semangat investigatif ini harus selalu ada baik dalam pencarian data, pengumpulan serta penyusunan informasi. ${ }^{14}$

Metode riset seperti ini dilakukan oleh Richard Bulliet dengan memulai investigasi dari individu atau kelompok individu dari suatu komunitas kecil. Pada masyarakat seperti ini, seorang peneliti sejarah sosial akan menemukan ragam dan level bahasa berbeda, mereka adalah masyarakat yang menikmati ragam keberagamaan dengan kekayaan perpaduan antara agama dan kultur. Misalnya pada satu subbab dalam bukunya yang berjudul Ulama, Bulliet menjelaskan tentang dinamika transmisi Hadith yang diperankan oleh keluarga keturunan dari Arab (syarif/sayyid), yakni kisah keturunan Abu Bakr yang memiliki pengaruh bagi kehidupan beragama masyarakat Jurjan di awal abad ke-11. Dengan mengambil sumber dari karya Hamzah alSahmi, seorang sejarawan Jurjan, Bulliet menjelaskan peran keturunan Abu Bakr Al-Isma'ily sebagai keluarga ulama yang memiliki garis keturunan mulia dari Nabi Muhammad juga memiliki pengaruh politik, otoritas keagamaan, hingga kekuasaan ekonomi di wilayah Jurjan.

Pada investigasinya, Bulliet merumuskan ada tiga aspek penting yang berpengaruh dalam membentuk otoritas keulamaan dari satu generasi ke generasi lainnya dari keturunan ini. Aspek pertama adalah keseriusan keluarga ini dalam mendidik anak dan keturunannya untuk belajar Hadith kepada para ulama, terutama para generasi laki-laki. Keseriusan dalam menggali Hadith dari para ulama akhirnya menjadikan keluarga ini sebagai ulama Hadith yang disegani oleh masyarakat awam Jurjan. Anak, menantu dan cucu al-Isma'ily kesemuanya adalah ulama' Hadith, bahkan beberapa dari mereka

${ }^{14}$ Kuntowijoyo, Sejarah, 46. 
memiliki ḩalaqah pengajian di masjid ataupun tempat-tempat lainnya di Jurjan. Sampai di sini Bulliet menyimpulkan, keutamaan garis keturunan yang diikuti dengan disiplin keras dalam transmisi pengetahuan adalah modal utama. ${ }^{15}$

Disisi lain, Bulliet dengan tajam juga melihat bahwa aspek pembelajaran (learning) bukanlah satu-satunya faktor yang membentuk keulamaan keluarga al-Ismai'ly. Hal ini terbukti pada salah satu anggota keluarga mereka, yakni Muhammad al-Jaulaki termasuk ulama yang kurang tersohor dan tidak memiliki cukup pengaruh, namun karena kebesaran nama keluarga keulamaan Jaulaki kemudian tetap bertahan. Faktor lain yang mempengaruhi adalah faktor kekuasaan (power) yang menjadi aspek kedua yang tidak boleh diabaikan dalam melihat kegemilangan otoritas keulamaan keluarga al-Ismai'ly di Jurjan. Bulliet menyebut peran Abu Bakr Al-Ismai'ly sebagai penasehat walikota (Ra'is) adalah peletak dasar kekuasaan keagaaman dari keluarga ini. Anak beliau Abu Nasr al-Ismaili kemudian menjadi walikota (Rais) sementara anak lainnya (Abu Sa'd) menjadi ahli hukum yang bekerja untuk Rais.

Faktor ketiga yang berpengaruh dalam menentukan otoritatifnya keluarga al-Ismaily adalah faktor ekonomi (money). Sementara data alSahmi mengenai pekerjaan masyarakat Jurjan mayoritas adalah pedagang, pekerja, dan pengrajin dari peralataan kuda. Mertua Abu Bakr yang bernama Abu Thaiba' adalah seorang saudagar dan petani kaya raya yang dengan professional telah membagikan warisannya kepada seluruh anak dan cucu laki-lakinya. Dari sinilah keluarga Abu Bakr mempertahankan kekuatan ekonomi mereka. ${ }^{16}$

Pada akhir ulasannya yang berkaitan dengan studi Hadith, Bulliet menyimpulkan bahwa di era-era awal transmisi Hadith (sebelum masa tadwin kitab), pembelajaran Hadith bersifat personal tetapi peran keluarga amatlah penting, sehingga membentuk sebuah transmisi keluarga. Peran mereka selain memberikan pengaruh otoritatif Hadith di hadapan komunitas mereka, pada saat yang sama juga merupakan suporter bagi pandangan mazhab tertentu di daerah tersebut. Keluarga al-Ismaily, sebagaimana disimpulkan Bulliet dari al-Sahmi, adalah pendukung dari mazhab Syafi'y, di era ketika mayoritas muslim Iran adalah eksponen dari mazhab Hanafi, sementara dunia Islam sedang asyik masyuk dalam kekuasaan kaum Sufi. Meskipun samasama bermazhab sunni, tetapi masa itu merupakan berkembangnya

${ }^{15}$ Bulliet, Islam, The View, 106

${ }^{16}$ Ibid., 109. 
fase intoleransi (konflik dan kekerasan) antar mazhab di dalam sunni sendiri. Baru di akhir abad ke-12 toleransi antar mazhab itu terjadi, karena masing-masing pihak memahami titik perbedaan dari cara istinbäțatau ittifäq hukum masing-masing dari mereka. ${ }^{17}$

Menurut perspektif sejarah sosial pinggiran, tarikh Jurjan adalah representasi dari dari dinamika sosial masyarakat muslim lokal. Sebuah narasi sejarah lokal yang sedang berhadap-hadapan dengan kaum kosmopolit Sufi. Lebih jauh, Bulliet menyebut narasi ini sebagai "cosmopolitanism versus localism, rationalism versus mysticism, and legalism versus faith in hadith as the best guide to muslim behavior". "Bila menggunakan sejarah konvensional, cara pandang pusat (central) pada saat itu adalah para ulama Hoja di Turkey atau Mullah di Iran yang diketahui lebih otoritatif sebagai perangkat keualamaan dan para teladan moral, dan narasi besar sejarah menyebutnya sebagai pihakpihak yang memiliki tanggung jawab dan representasi penuh dalam hal keislaman.

Maka ulasan Tarikh Jurjan bicara dari sudut pandang pinggiran itu mengungkap tentang cerita kapan, bagaimana, dan mengapa kelompok kecil yang ada di pinggiran itu kemudian dengan legowo (lapang dada) merapat, bahkan ditakdirkan menjadi bagian dari seluruh cerita kebesaran Islam. Cara pandang pinggiran tidak memulai cerita dari sudut pandang geografis, atau politik. Sudut pandang pinggiran memulai dari kapan atau dimanapun masyarakat secara dinamis berusaha menentukan dirinya untuk "menyeberangi" batasan-batasan dirinya sendiri" ${ }^{19}$, kemudian masuk dan menjadi muallaf, lalu mendedikasikan dirinya bagi islam, dan menjadikan islam sebagai bagian dari identitas integral kehidupan mereka.

\section{Kontribusi Sejarah Sosial Untuk Living Hadith}

Tarikh Jurjan sebagaimana kemudian disampaikan kembali oleh Richard Bulliet merupakan suatu sejarah totalitas (total history) ${ }^{20}$ dari

17 Ibid., 110.

${ }_{18}$ Bulliet, Islam, The View, 111.

19 Pada sub-bab awal Tarikh Jurjan bercerita tentang gelombang masuknya masyarakat pinggiran Iran untuk masuk Islam (muallaf) yang juga menyebabkan adanya urbanisasi di wilayah Iran. Ibid., 67.

20 Sejarah-total diartikan sebagai historiografi total dimana tidak hanya menelaah aspek politik saja yang menjadi acuan penulisan sejarah. Aspek-aspek lain seperti geografi dan ekonomi, dalam hal ini juga aspek keagamaan, juga perlu diperhatikan. Peter Burke, Sejarah Sosial dan Teori Sosial, edisi kedua, (Jakarta: Yayasan Pustaka Obor Indonesia, 2015), 107. 
suatu masrakat lokal yang tidak hanya berfokus pada aspek regenerasi politik. Tetapi melalui eksplorasi dinamika sosial dan kegamaan, tarikh Jurjan mampu menarasikan perjalanan politik melalui ruang lingkup kehidupan masyarakat lokal yang elbih menyeluruh. Dalam hal studi living Hadith narasi sejarah sosial amatlah penting. Para kasus Tarikh Jurjan dokumentasi tentang perjalanan transmisi Hadith di daerah ekspansi Islam, dialog dan dialektika antar mazhab melalui dukungan aktif antar generasi dari suatu keluarga, juga ruang lingkup otoritas Hadith dan otoritas keluamaan dalam ruang lingkup masyarakat lokal; kesemuanya dapat dirangkum dalam narasi sejarah sosial pinggiran ini (periphery). Aspek lain yang juga amat sayang untuk dinafikan adalah bukti keterhubungan interaksi antara Islam universal dan saling keterpengaruhannya dalam konteks lokal juga terjadi. Seperti pentingnya peran ulama dari garis keturunan para sayyid atau syarif; keterlibatan para tokoh lokal untuk melakukan urbanisasi demi perjalanan learning, dalam hal ini transmisi Hadith, termasuk pula di dalamnya pentingnya sanad bagi keilmuan Hadith dan keagamaan masyarakat muslim secara umum; kesemuanya merupakan faktorfaktor universal yang akan selalu muncul di beragam masyarakat muslim di belahan bumi ini. Unsur global dan unsur lokal serta keterhubungan antara keduanya dalam dinamika sejarah merupakan obyek material utama dari kajian living Hadith dengan perspektif sejarah sosial. ${ }^{21}$ Lalu bagaimana tema dialektika antara unsur global dan unsur local Islam melalui eksplorasi sejarah sosial pinggiran dapat berkontribusi secara metodis bagi studi living Hadith.

Kehidupan masyarakat muslim Indonesia yang sarat akan budaya itu sebenarnya unik sekaligus bersifat global ini amat penting untuk

21 Dari sisi kultural-antropologis, dinamika sosial ini disebut sebagai fase universalisasi dan fase parokialisasi. Universalisasi merupakan proses dimana unsurunsur budaya populis yang direpresentasikan oleh budaya setempat mengalami objektifasi atau penerimaan masyarakat secara lebih luas tanpa disertai keraguraguan akan dasar teksnya. Sementara parokialisasi atau kontekstualisasi adalah proses dimana narasi-narasi besar agama yang berasal dari budaya tinggi seperti terdapatnya tansmisi teks, proses pembelajaran teks-teks kunci, dan sebagainya disampaikan kepada masyarakat awam melalui medium budaya local yang populer. Contoh dari universalisasi adalah tradisi mudik di Indonesia, dimana masyarakat muslim secara umum menerima tanpa mempermaslahkan dasar teks atau ajaran agama yang secara spesifik merujuk padanya. Sementara contoh dari parokialisasi atau kontekstualisasi adalah selamatan-tahlilan, atau perayaan selapanan bagi bayi yang baru lahir. Ulasan lebih jauh baca, Ronald A. Lukens-Bull, "Between Text and Practice: Considerations in the Anthropological Study of Islam". Journal of Religious Studies, Phillips Marbourg University, Volume 4, No.2, December 1999, 2. 
dinarasikan melalui sejarah sosial. Ia unik karena pengaruh HinduHudha dari sejarah masyarakat muslim Indonesia (baca nusantara) menyebabkan Islam Indonesia memiliki karakter tersendiri, dari misalnya Islam Persia, Timur Tengah, tentu saja islam di negeri atas angin, Arab. Pada saat yang sama sejarah narasi Islam yang sampai ke Indonesia juga merupakan hasil pengaruh dari beragam jaringan keulamaan yang dinamis dan panjang, melibatkan seluruh unsur keilmuan dalam islam, seperti tasawuf, fiqh, aqidah, tentu saja tafsir dan kekayaan keulamaan Hadith. Aspek yang terakhir ini menyebabkan islam Indonesia (nusantara secara umum) tidaklah dapat dipisahkan dari sejarah islam global. Dalam ruang lingkup dialog unik-global tersebut, living Hadith ingin menekankan karakter utama dari proses transmisi Hadith yang selalu ada, yakni otoritas Hadith yang tidak melulu bersifat literatif-tertulis (literacy, written), tetapi secara jelas adalah otoritas yang berkarakter oralitas (orality, sounds). ${ }^{22} \mathrm{Hal}$ ini terbukti melalui, misalnya garis sanad para ulama Hadith yang selalu tersambung hingga kepada Nabi Muhammad.

Selain faktor dialektik antara lokal-global dan keterhubungan karakter oralitas para ulama, seorang peneliti sejarah sosial living Hadith juga dapat mengeksplorasi ragam dinamika transmisi Hadith baik sebagai ajaran Islam maupun sebagai sebuah tradisi keilmuan di pesantren sebagai institusi pendidikan islam yang khas di Indonesia. Persoalan yang terjadi hingga akhir abad ke-20 adalah, mengapa kitab-kitab Hadith yang diajarkan di pesantren di Indonesia umumnya lebih menitikberatkan aspek ajarannya pada fikih dan akhlak. ${ }^{23}$ Bagaimana

22 Dengan cukup lugas Richard Bulliet mengilustrasikan keragaman Islam yang total sekaligus fragmented ini sebagai "a house with many rooms". Dalam ruang lingkup keragaman ini, keberadaan ulama sebagai figure sentral dari otoritas hadith dan agama secara umum semakin menekankan karakter khas dari living hadith, yakni faktor transmisi oralitasnya. Lebih jauh ia menjelaskan: "Islam in Gorgan is different from Islam in Isfahan or Nishapur. It differs even more from Islam in Cordoba, Qairawan, Cairo, and Damascus. Local religious authority is embodied in the local corpus of hadith, and even more in the locally prominent families of ulama. To be sure, collections of "sound" traditions are already acquiring a supralogical legitimacy, but on the local power, pride, and particularism of the ulama will survive for another bundred years. Bulliet, Islam, The View, 114.

23 Dari riset yang dilakukan oleh Muhammad Yunus hingga tahun 1920an, setidaknya terdapat tiga cluster kitab-kitab Hadith yang dipelajari oleh pesantren di Indonesia, yakni kitab primer, kitab sekunder (antologi), dan kitab syarah atau ulumul hadith. Di antara ketiganya, kitab antologis seperti Kitab Riya $>$ d al$\mathrm{S}\{\mathrm{a}>\operatorname{lih}\} \mathrm{i}>\mathrm{n}$ karya Abu $>$ Zakariyyah Muhy al-Di $>$ n al-Nawa $>$ wi; kitab al-Adab alNabawi> karya Muhammad 'Abd al-'Azi $>$ z al-Khu $>$ li $>$, dan kitab Bulu>gh alMara $>$ m karya Ibn $\mathrm{H}$ \{ajar al-'Asqala $>$ ni $>$ yang paling sering digunakan sebagai referensi studi hadith di pesantren-pesantren di Indonesia. Pada kitab-kitab seperti 
karakter fikih-sufistik ini berpengaruh terhadap pembentukan karakter pemikiran di pesantren yang bertumpu sepenuhnya pada ketertundukan para santri terhadap mazhab fikih, bagaimana kondisi ini berpengaruh, misalnya, di pesantren Banjar atau Lampung atau mungkin juga di Jombang dimana masing-masing dari daerah tersebut juga memiliki struktur budaya keagamaan yang sedikit banyak berbeda? ${ }^{24}$

Sejarah sosial yang juga layak untuk diperhitungkan dalam kaitannya dengan karakter pembelajaran Hadith di berbagai pesantren di Indonesia adalah hubungannya dengan isu gender. Bagaimana

ini hadith disajikan sebagai materi "siap saji" yang sudah diseleksi, diproses, dan dikutip untuk kepentingan suatu tema pembahasan. Hadith-hadith tersebut dihadirkan dalam suatu "menu siap hidang dan siap santap". Martin Van Bruinessen, Kitab Kuning, Pesantren dan Tarekat (Bandung: Mizan, 1999), 161.

24 Pertanyaan seperti ini dapat dimunculkan oleh peneliti living hadith dengan pendekatan sejarah sosial, karena konteks sosial dari masing-masing daerah yang dapat digambarkan sebagai berikut: Bagi kaum muslim Sunni, selain Nabi, sahabat dan tabi'in, otoritas dalam menafsirkan agama (baik kitu atas al qur'an, fikih, termasuk pula di dalam nya adalah Hadith) berada di tangan para ulama madzhab. Mereka memperoleh otoritas penafsiran berdasarkan pengetahuan dan kesalehan mereka yang dinilai secara luas. Bagi kelompok Islam tradisional, masyarakat pesantren, otoritas ulama mazhab menjadi mutlak dan dianggap telah memenuhi kebutuhan umat Islam sehingga pengembangan penafsiran yang langsung merujuk kepada al qur'an dan hadith dengan tanpa melalui pemahaman atas empat madzhab sunni adalah hal yang tidak mungkin dilakukan. Birokratisme dalam pemahaman agama ini berdampak pada dominannya kajian yang berlandas pada fikih dan tasawuf, sementara tradisi keilmuan sebagai perangkat ijtihad seperti ushul fiqh, tafsir, hadith, apalagi filsafat jarang dipelajari. Karel A. Steenbrink, Pesantren, Madrasah, Sekolah: Pendidikan Islam dalam Kurun Modern (Jakarta: LP3ES, 1986), 130-1. Ketiga contoh kota yang disebutkan oleh penulis di atas memungkinkan untuk melihat bagaimana kondisi sosial dan budaya masing-masing dari masyarakat memiliki implikasi berbeda terhadap struktur pendidikan transmisi hadith sebagaimana disebutkan oleh Steenbrink. Jombang misalnya, sebagai salah satu kota dengan banyak pesantren dan merupakan tempat dari salah satu pesantren tertua di Indonesia memungkinkan kuatnya pengaruh pemikiran para ulama' terdahulu. Sementara di Lampung misalnya sebagai konsekuensi dari perpindahan penduduk Jawa terdapoat pula pesantren yang dihuni dan didirikan oleh para transmigran. Bagaimana konteks masyarakat Jawa-transmigran yang tidak lagi terkungkung oleh feodalisme Jawa masih tetap mempertahankan atau mentransformasikan karakter pembelajaran hadith seperti di Jawa? Atau di Banjar misalnya, dengan struktur sosial budaya yang sedikit berbeda, dimana peran para tuan guru lebih dominan dari di Jawa juga akan memunculkan dinamika sosial yang berbeda? Sejarah sosial atas transmisi hadith di berbagai kota tersebut memungkinkan adanya pertautan antara karakter kahs dari amsing-masing daerah, tetapi sekaligus dapat menguji karakter global dari islam sunni di Indonesia. 
misalnya, tumbuhnya kesadaran dan pemikiran gender di akhir abad ke-20 memiliki implikasi secara sosial terhadap pemahaman masyarakat pesantren atas Hadith-Hadith misoginis. Bila hal itu terjadi, bagaimana dinamika sosial dan dialektika pemikiran kritis atas Hadith (tentu melalui kajian fikih) itu terjadi di masyarakat pesantren di Indonesia. ${ }^{25}$

Selain aspek-aspek utama dari karakter tranmisi Hadith, riset living Hadith dengan pendekatan sejarah sosial juga tidak mengecualikan pada proses transmisi dan tranformasi suatu tematik Hadith atau isu sosial di suatu komunitas masyarakat muslim berlangsung. Bagaimanakah kesesuaian dari unsur global dilakukan oleh komunitas muslim tersebut melalui praktik local mereka, sebagai sebuah metode, sejarah sosial untuk living Hadith tidak dimulai dari narasi besar para kaum elite, tetapi historiografi diawali dari bawah, yaitu dari rakyat yang populis. Dengan demikian proses sejarah tidak ditentukan oleh dinamika politik, tetapi dinamika masyarakat pada umumnya. Misalnya, penelitian tentang sunat perempuan tidak dimulai dengan mengeksplorasi narasi dari MUI atau pemerintah, tetapi bagaimana komunitas kecil seperti di suatu desa di Sukoharjo, atau di Bandung Jawa Barat, bahkan juga di Madura bertahan dengan mempraktikkan tradisi tersebut. Maka narasi sejarah dapat dimulai dari adanya para tokoh ulama desa, peran dan otoritas mereka dalam transmisi dan transformasi Hadith ke masyarakat, lalu bagaimana masyarakat mampu bertahan dengan mempraktikan sunat perempuan melalui

${ }^{25}$ Meski belum tentu menggunakan sejarah sosial sebagai perspektif kajian dan focus studi pada kajian hadith, beberapa penelitian di bawah ini memperbincangkan bagaimana otoritas para ulama itu menghadapi dinamika dan dialektika secara sosial dengana danya pengaruh perspektif gender. Seperti: Pieternella van-dorn Harder, Women Shaping Islam; Reading the Qur'an in Indonesia, (USA: UVA Press, 2006); Susan Blackburn, Indonesian Islam in a New Era, (Australia, Monash University Press, 2008); Jajat Burhanuddin, dkk. Ulama Perempuan Indonesia, (Jakarta: Gramedia Pustaka, 2002); Bianca J. Smith dan Mark Woodward (ed.), Gender and Power in Indonesian Islam; Leaders, Feminists, and Pesantren Selves, (USA, Routledge, 2014). Riset-riset ini tentu belum termasuk karya para tokoh ulama perempuan dan gender di Indonesia, seperti KH. Husein Muhammad, Mencintai Tuhan, Mencintai Kesetaraan, Jakarta: Elex Media Komputindo, 2014); Maria Ulfah Anshor, Memutus Rantai Ketidakadilan Global Care dalam pengasuban Anak TKI Perempuan, (Jakarta: Yayasan Obor, 2010), Lies Marcoes, Johan Hendrik Meuleman (ed.), Wanita Islam Indonesiaa dalam Kajian Tekstual dan Kontekstual, (Jakarta: INIS, 1993); Syafiq Hasyim, (ed.), Menakar Harga Perempuan, (Bandung: Mizan Pustaka, 1999). 
akulturasi budaya (yang juga melibatkan budaya populer) di antara diskursus nasional tentang sunat perempuan. ${ }^{26}$

Dari sini kita bisa menarik kesimpulan, bahwa perspektif sejarah sosial yang menekankan pada apa yang sebut Bulliet sebagai "the view from the edge". Yakni menarasikan sejarah yang berusaha untuk melengkapi cara pandang Islam dominan (sebagaimana dilihat dari pusat, dari aspek politis, yang serba formal dan bersifat legalistik), menuju cara pandang pinggiran memulai dari kapan atau dimanapun masyarakat secara dinamis berusaha menentukan dirinya untuk "menyeberangi" batasan-batasan sosio-kultural dirinya sendiri, secara dinamis mendialogkan aspek universal islam dan faktor lokalitas mereka, lalu mendedikasikan dirinya sebagai bagian dari islam, dan menjadikan islam sebagai bagian dari identitas integral kehidupan mereka.

\section{Kesimpulan}

Sebagaimana diulas di atas mengenai asumsi dasar dari studi sosial yang melihat islam sebagai komunitas global yang dinamis, implikasi dari cara pandang sejarah sosial tidak pernah memandang suatu sejarah sebagai suatu narasi yang utuh. Dari Ibn Khaldun dan Tarikh Jurjan Hamzah al Sam'ani kita bisa mendapatkan gambaran bahwa sejarah masyarakat muslim adalah ragam fragmen, ragam sejarah lokal yang berbeda-beda, bahkan terkadang bagi mereka yang lebih fokus pada perspektif politik, sejarah sosial kadang dianggap miskin data.

Tetapi kontribusi sejarah pinggiran bagi studi living Hadith, bagaimanapun juga, tidak terbantahkan. Keberadaan ijazah sebagai penyambung otoritas keulamaan melalui tradisi sanad merupakan bahasa lain dari dokumentasi transmisi (atau juga transformasi) Hadith di masyarakat, yang merupakan tema penting dalam studi living Hadith. Otoritas Hadith tidak berlangsung secara statis. Bahkan bagi masyarakat berlatar belakang sunni yang memiliki keterikatan

26 Subkhani Kusuma Dewi, The Role of Ulama in Indonesia Contesting FGC and Advocating Women's Sexual Identity (Case Study of Jetis Village, Baki, Central Java). Makalah dipresentasikan pada " $4^{\text {th }}$ FOKO Conference on FGC in the Past and Today", diselenggarakan oleh Hanasaari The Sweedish-Finish Cultural Center in Espoo-Finland, 2008. Referensi lainnya, Basilica Dyah Putranti, Sunat Perempuan: Cermin Bangunan Sosial Seksualitas Masyarakat Yogyakarta dan Madura, Jurnal Populasi, Vol. 16, No. 1, 2005. Andre Feillard \& Lies Marcoes, Female Circumcision in Indonesia; To "islamize" in Ceremonony or Secrecy, Jurnal Archipel Vol. 56, Tahun 1998, 337-367. Kajian terhadap tema dalam studi living hadith pada dasarnya menjawab persoalan "apa peran agama pada masyarakat muslim tsb? Kepada siapa masyarakat awam itu menaruh kepatuhan mereka? siapa juga yang merespon kebutuhan-kebutuhan masyarakat awam ini?" 
terhadap imam mazhab seperti pada kisah komunitas muslim Jurjan ataupun komunitas pesantren di Indonesia, dinamika sosial-kultural tetaplah terjadi. Narasi sejarah sosial pada konteks ini akan membantu living Hadith untuk dapat menghadirkan sejarah total. Dengan kata lain, living Hadith dengan pendekatan sejarah sosial akan mampu menyuguhkan bukti bahwa suatu otoritas atau kewenangan Hadith para local religious leaders tidak akan mungkin diakui bila tidak ada penerimaan masyarakat sebagaimana diekplorasi ragam dimensinya (ekonomi, sosial, politik, agama) melalui sejarah sosial. Terakhir, Living Hadith dapat mengambil metode Richard Bulliet yakni sejarah sosial, yang bertugas untuk menjelaskan kepada generasi mendatangkan akan sebuah perkembangan secara integrative yang tidak bisa hanya diperankan oleh sejarah politik.

\section{Daftar Pustaka}

Abbott, Nabia. "Early Islamic Historiography", dalam Studies in Arabic Literary Papyri I: Quranic Commentary and Tradition. Illinois: The University of Chicago Press, 1967.

Afwadzi, Benny. Membangun Integrasi Ilmu-ilmu Sosial dan Hadith Nabi, Jurnal Living Hadith, Vol. 1, No. 1, 2016. ejournal.uinsuka.ac.id/ushuluddin/Living/article/view/0101-05. DOI: https://doi.org/10.14421/livingHadith.2016.0101-05.

Anshor, Maria Ulfah. Memutus Rantai Ketidakadilan Global Care dalam pengasuban Anak TKI Perempuan. Jakarta: Yayasan Obor, 2010.

Blackburn, Susan. Indonesian Islam in a New Era. Australia, Monash University Press, 2008.

Bulliet, Richard. Islam, The view from The Edge. USA: Columbia University Press, 1994.

Bruinessen, Martin Van. Kitab Kuning, Pesantren dan Tarekat. Bandung: Mizan, 1999.

Burhanuddin, Jajat, dkk. Ulama Perempuan Indonesia. Jakarta: Gramedia Pustaka, 2002.

Burke, Peter. Sejarah Sosial dan Teori Sosial. Jakarta: Yayasan Pustaka Obor Indonesia, 2015.

Dewi, Subkhani Kusuma. The Role of Ulama in Indonesia Contesting FGC and Advocating Women's Sexual Identity (Case Study of Jetis Village, Baki, Central Java). www.scribd.com/document/457763/Paper-FOKO-EnglishVersion. 
Feillard, Andre \& Lies Marcoes. Female Circumcision in Indonesia; To "islamize" in Ceremonony or Secrecy. Jurnal Archipel Vol. 56, Tahun , 1998.

Harder, Pieternella van-dorn. Women Shaping Islam; Reading the Qur'an in Indonesia. USA: UVA Press, 2006.

Hasyim, Syafiq (ed.). Menakar Harga Perempuan. Bandung: Mizan Pustaka, 1999.

Khaldun, Ibn, Muqaddimah Ibn Khaldun, diterjemahkan oleh Masturi Irham, dkk. Jakarta: Pustaka Al Kautsar, 2001.

Kuntowijoyo. Metodologi Sejarah. Yogyakarta: Penerbit Tiara Wacana, 2003.

Lukens-Bull, Ronald A. "Between Text and Practice: Considerations in the Anthropological Study of Islam". Journal of Religious Studies. Phillips Marbourg University, Vol 4, No.2, December 1999.

Marcoes, Lies. Johan Hendrik Meuleman (ed.). Wanita Islam Indonesiaa dalam Kajian Tekstual dan Kontekstual. Jakarta: INIS, 1993.

Muhammad, Husein. Mencintai Tuhan, Mencintai Kesetaraan. Jakarta: Elex Media Komputindo, 2014.

Putranti, Basilica Dyah. Sunat Perempuan: Cermin Bangunan Sosial Seksualitas Masyarakat Yogyakarta dan Madura. Jurnal Populasi, Vol. 16, No. 1, 2005.

Qudsy, Saifuddin Zuhri. Living Hadith; Genealogi, Teori, dan Aplikasi. Jurnal Living Hadith, Vol. 1, No. 1, Tahun 2016. Ejournal.uinsuka.ac.id/ushuluddin/Living/ article/view/0101-08. DOI: https://doi.org/10.14421/livingHadith.2016.0101-08.

Steenbrink, Karel A. Pesantren, Madrasah, Sekolah: Pendidikan Islam dalam Kurun Modern. Jakarta: LP3ES, 1986.

Smith, Bianca J. dan Mark Woodward (ed.). Gender and Power in Indonesian Islam; Leaders, Feminists, and Pesantren Selves. USA, Routledge, 2014. 